Relations industrielles

Industrial Relations

\title{
The Legality of Union Security Provisions
}

\section{Louis-Philippe Pigeon}

Volume 4, numéro 10, juin 1949

URI : https://id.erudit.org/iderudit/1023549ar

DOI : https://doi.org/10.7202/1023549ar

Aller au sommaire du numéro

\section{Éditeur(s)}

Département des relations industrielles de l’Université Laval

ISSN

0034-379X (imprimé)

1703-8138 (numérique)

Découvrir la revue

Citer cet article

Pigeon, L.-P. (1949). The Legality of Union Security Provisions. Relations industrielles / Industrial Relations, 4(10), 91-94.

https://doi.org/10.7202/1023549ar

Tous droits réservés (C Département des relations industrielles de l’Université Laval, 1949
Ce document est protégé par la loi sur le droit d'auteur. L’utilisation des services d'Érudit (y compris la reproduction) est assujettie à sa politique d'utilisation que vous pouvez consulter en ligne.

https://apropos.erudit.org/fr/usagers/politique-dutilisation/ 


\section{Bulletin des nelations industrielles}

Volume 4, number 10

QUEBEC

June 1949

\author{
Published by the \\ Department of Industrial Relations, \\ Faculty of Social Sciences, \\ Laval University. \\ Georges-Henti Levesque, o.p., Dean \\ Gérard Tremblay, Director \\ GÉRARd Dion, Assistant-Director \\ Jean Gagné, Secretary \\ Charles BÉlanger, Administrator
}

The Bulletin is published monthly, September to June inclusively (ten issues a year). Annual subscription: Canada: \$2.00; Foreign: $\$ 2.50$. Single copies: twenty-five cents.

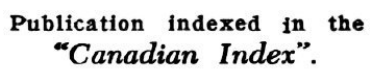

All correspondance must be addressed to the Literary Editor Gérard Dion

2, University Street, Quebec.

Bulletin des relations industrielles

Volume 4, number 10 June 1949

\section{Contents}

The Legality of Union Security Provistons,

Louis-Philippe Pigeon.

Trades which are Dying in the Construction Industry,

Marcel Clément.

The Economy must be placed at the Service of Mankind,

Paul-H. Plamondon.

Future Aims of the Collective

Agreement,

JacQues Archambault.

Index 1948-1949

\section{Contributors}

Archambault, Jacques, B.A., M.Soc.Sc., Secretary, Central Council of the National Catholic Syndicates of Joliette.

Clément, Marcel, Professor, Faculty of Social Sciences, Laval University.

Pigeon, Louis-Philippe,K.C., Lawyer, Quebec Bar, Professor in the Faculties of Law and Social Sciences of Laval University.

Plamondon, Paul-H., President, Quebec Board of Trade, Proprietor H. Thivierge Le Costumier Enr., Quebec.

\section{THE LEGALITY OF UNION SECURITY PROVISIONS}

\author{
Ls-Philippe Pigeon
}

\section{What makes the problem difficult}

The fact that in the final analysis it is one of the aspects of the problem of legal freedom, makes this a difficult question.

The first principle of law may be stated as follows: «All that is not prohibited, is permitted. » Although quite simple; this principle is very difficult to apply. Freedom, in fact, cannot be conceived without restrictions because it is necessary to prevent anyone from using his freedom to destroy the freedom of others.

Institutions designed to secure freedom are therefore difficult to set up and complicated. Under a dictatorship, the problem of freedom does not arise: «orders》 must be obeyed. Nothing limits the «orders ». When one believes in freedom, one cannot be satisfied to believe in it, it must be defined. Therefore, certain acts, must be prohibited, especially those which are prejudicial to others. What is prejudicial to others is not always clear. Very few activities do not cause prejudice to a certain extent; it is therefore necessary to define what is meant by prejudice. Thus in the field of relations between owners of neighbouring buildings it is said that one must submit to ordinary inconveniences such as smoke from usual chimneys.

Freedom not being absolute, freedom of association does not therefore mean that trade unions may demand any union security clause. Some restriction is necessary. The Taft-Hartley Act came as a justifiable reaction against what was wrong in the Wagner Act based as it was on unrestricted freedom for the unions, defining rights only for the unions and duties only for the employers. It must not be forgotten that in the United States, many trade unions in their constitutions, claim to be above the law, to be sole judges of what their action should be and from this is derived their contention that they are not bound to obey court injunctions.

The problem of union security is largely due to the fact that on the one hand unions claim absolute rights, and on the other hand some employers refuse any form of union security. Justice is, however, between the two extremes.

Note of the Editor:-We are presenting here a résumé of a lecture given at the Faculty of Social Sciences. 
Workers should not be bound to any union. On the other part, a certain degree of coercion may properly be demanded to prevent workers' associations from always being obliged to fight for their existence.

\section{Provincial legislation}

Opinions are very divided as to what our law permits. The question has not yet been the subject of decisions of our courts of law it has been considered only in arbitration awards and in writings in periodicals.

In my opinion, the present Provincial act does not prohibit any form of union security. There are jurists who hold contrary views, but, after considering their arguments, I cannot agree that their objections are well founded except in the case of some workers covered by minimum wage orders. These orders prohibit any deduction which would have the effect of reducing the wage paid below the minimum fixed by the order. Consequently a clause of union security which would require a deduction of this nature, would be void. Such could be the case only in exceptional circumstances because collective agreements usually provide for wages higher than the minimum.

Under our Provincial law, there are no other restrictions. The provision against which one can make the strongest legal argument is the union shop, which compels a new employee to join the union or to lose his job. The basis of this argument is that the Labour Relations Act prohibits any one from using threats to get a worker to join a union. However, this same act does not otherwise interfere with the employer's right of dismissal.

1. Closed Shop.-No argument based on a text of the act may be invoked against this clause. The employer is free to hire whoever he pleases. The worker who is not yet in the service of the employer has no legal right to be hired. Therefore, the employer certainly has the right not to hire a worker who is not a union member.

The texts concerning discrimination in hiring contemplate only a refusal of employment because one is a member or an officer of an association. The closed shop clause is therefore legally admissible. There is no doubt on its legality. The text dealing with discrimination in hiring does not say « because he is a member or because he is not a member.» This last text which existed previously has been repealed. This reveals very clearly that the intention of the Legislature was not to prohibit such a clause. This being so, how could one hold illegal another clause which is much less strict; the union shop agreement. From the economic point of view, the closed shop may however be somewhat dangerous for the employer. Except in certain industries e.g. construction, where one is dealing with unions who have a large number of members, a real labour supply, the rights of management might be seriously curtailed by the application of such a clause.

2. Union shop.-We have just seen that according to the Labour Relations Act, the closed shop is undoubtedly permitted. This might of itself be practically sufficient to dispose of all arguments against the legality of the union shop and especially of the imperfect union shop. If the closed shop may be lawfully demanded, the employer has no interest to discuss the legality of much less rigid clauses.

The legal objection to the union shop must however be considered, especially because of its application to employees already in the service of the employer. This objection is based on section 22 of the Labour Relations Act which prohibits the «use of intimidation or threats to induce anyone to become a member of an association. » Is not the employer using threats towards his employees in subscribing to this clause ? I do not think so. From a legal point of view the worker has no right to his job beyond the period for which he is bound to his employer. In industry employment is usually by the hour. Therefore the contract may be ended at each hour. The employer, in dismissing workers at will is exercising his undoubted right and does not have to justify his motives, except in the case of dismissal for union activity. Here, it is not activity but nonactivity. The clause does not require the employer to use any threat. He may enforce it without making any threat whatever. If it becomes necessary, he may have to dismiss some workers, nothing else is being asked of him.

Any employee may undoubtedly quit his job without giving any reason. The employer also may put an end to the contract for the services of any employee. It is a well recognized civil law principle that the exercise of a legal right is not a threat. Thus, although contracts made under threats are subject to annulment a debtor can- 
not claim the return of onerous guarantees that he has given under the pressure of legal action. In the same manner, an employer may not contest the validity of a collective agreement obtained by his workers using their right to strike.

Conclusion: even the perfect union shop clause is valid. This implies the validity of all the other forms of union security. However, the Rand formula or compulsory check-off of union dues requires special consideration although the union shop or the closed shop are more drastic.

3. Rand formula or compulsory check-off.-On this point another objection must be considered, namely whether this is a «condition of employment ». In my opinion, this expression includes everything that concerns relations between employer and employee. Much is made of the case of Lazarovitz vs Court of Sessions (69 K.B. 214) which really dealt with prices to be charged to the public by employers. The principle applied in this case is the following: «However general are the words used, they must be restricted to the subject-matter of the legislation in which they are found ». In the Collective Agreement Act, the expression «all other provisions》 interpreted literally would have meant anything. Therefore, the Court of Appeals said: The Act is concerned with a single thing; relations between employers and employees. The same principle must be applied in the construction of the Labour Relations Act and it drives one to the conclusion that everything that concerns relations between employers and employees may be the subject of provisions in collective agreements.

In France, the expression used in the French version of the Act: «conditions de travail» is unanimously construed as covering all relations between employers and employees including deductions from pay.

There is therefore no reason to doubt the validity of clauses for the check-off of union dues. The voluntary check-off really amounts to a partial assignment of debt which does not offer any difficulty under our law. One may even wonder if, even in the absence of a specific agreement, an employer could refuse it; he could do so only by dismissing the signatories; would these not be dismissals for union activity?

In the case of compulsory check-off, it is often said that an employer has no right to «tax » his workers. Let us note, in the first place, that no one raises any objection against compulsory contributions for such purposes as superannuation pensions. In law, the workers are not compelled to accept the deductions, but if they do not do so, they must quit. The collective agreement does not eliminate the individual agreements. These remain and retain their own conditions and they fix the duration of the employment. Usually these are short term contracts. The contract may be ended at will by either party. This right of cancellation enables the employer to establish any conditions which are not immoral. The worker is free to refuse them by quitting; otherwise, he accepts the conditions established. Let us observe how this reveals the necessity of union organization.

As already pointed out, minimum wage orders may make the check-off illegal in some exceptional cases. A decree could also have the same effect, for instance by enacting that higher salaries must be maintained.

One may sum up the legal situation in saying that the Labour Relations Act has not defined freedom of association otherwise than as being the right to be a member of an association and makes no mention of a socalled right not to be a member of any association at all.

\section{Federal Legislation}

Union security provisions are found in the Industrial Relations and Disputes Investigation Act (Bill 195).

In this Act there are two sections concerning this subject.

First of all, it is expressly provided that nothing shall prevent the insertion in a collective agreement of a clause requiring, as a condition of employment, membership in a specified trade union or granting a preference of employment to members of a specified trade union. Therefore all union security clauses are clearly legal.

In the second place, there is this restriction: no provision in a collective agreement may require an employer to dismiss an employee because he is a member of a union other than a specified union. I am of opinion that this has the result of preventing the application of the closed shop clause, when a worker is expelled from a union because of his membership in a rival union. If the employee has not yet been hired, he is merely prevented from obtaining employment and nothing 
prevents the application of the clause, but if he is already in the service of the employer, the union cannot require his dismissal.

The Federal Act has, therefore, sought to permit expressly all union security clauses while at the same time safeguarding the employees' right to quit a union enjoying a closed shop in order to join another association intended to be substituted to it as collective bargaining agent.

\title{
TRADES WHICH ARE DYING IN THE CONSTRUCTION INDUSTRY
}

\author{
Marcei Clément
}

During an inquiry that we have been carrying on in regard to the labour situation in the construction industry of the Province of Quebec, we have registered two particularly clear phenomena, of which the eventual consequences, unless a prompt remedy is found, may be quite serious. On one hand, it appears that certain categories of trades enjoy among youths an increasing and uncontrolled success, and, on the other hand, certain other categories are being deserted at an alarming rate.

Table I, below, indicates the number, by age group, of the apprentices and qualified journeymen of the eight principal trades in the construction industry, as has been revealed by a questimnaire filled on July 31,1948 . It must be taken into account that these figures:

a) do not cover the contractors, nor journeymen working for themselves, nor labourers, but exclusively qualified workers in the trades concerned;

b) only concern the districts controlled by a parity committee.

TABLE 1: NUMBER ESTABLISHED BY AGE GROUP, OF APPRENTICES AND QUALIFIED JOURNEYMEN OF THE EIGHT PRINCIPAL TRADES OF THE CONSTRUCTION INDUSTRY IN THE PROVINCE OF QUEBEC, AT JULY 31, 1948

\begin{tabular}{|c|c|c|c|c|c|c|c|}
\hline $\begin{array}{c}\text { Name of } \\
\text { Trade }\end{array}$ & $\begin{array}{l}\text { Number } \\
\text { of } \\
\text { Apprent- } \\
\text { ices }\end{array}$ & $\begin{array}{c}\text { Workers } \\
\text { less than } \\
25 \text { years } \\
\text { old }\end{array}$ & $\begin{array}{l}\text { Workers } \\
\text { between } \\
25 \text { to } 35 \\
\text { years old }\end{array}$ & $\begin{array}{l}\text { Workers } \\
\text { between } \\
35 \text { to } 45 \\
\text { years old } \\
\end{array}$ & $\begin{array}{l}\text { Workers } \\
\text { between } \\
45 \text { to } 55 \\
\text { years old } \\
\end{array}$ & $\begin{array}{c}\text { Workers } \\
\text { more than } \\
55 \text { years } \\
\text { old }\end{array}$ & $\begin{array}{c}\text { Total } \\
\text { number of } \\
\text { workers } \\
\text { employed in } \\
\text { each trade } \\
\end{array}$ \\
\hline Carpenters & 1,529 & 795 & 2,561 & 2,711 & 1,919 & 1,231 & 10,746 \\
\hline Bricklayers & 367 & 199 & 477 & 452 & 517 & 242 & 2,254 \\
\hline Plasterers & 308 & 74 & 201 & 381 & 320 & 158 & 1,442 \\
\hline Painters & 706 & 432 & 1,156 & 1,522 & 818 & 336 & 4,970 \\
\hline Plumbers & 2,321 & 487 & -780 & 727 & 326 & 187 & 4,828 \\
\hline Steamfitters & 378 & 82 & 134 & 95 & 54 & 20 & 763 \\
\hline Tinsmiths & 271 & 59 & 227 & 193 & 132 & 65 & 947 \\
\hline Electricians & 1,557 & 614 & 795 & 472 & 242 & 35 & 3,715 \\
\hline $\begin{array}{l}\text { Total number of workers } \\
\text { established by age group }\end{array}$ & 7,437 & 2,742 & 6,331 & 6,553 & 4,328 & 2,274 & 29,665 \\
\hline
\end{tabular}

